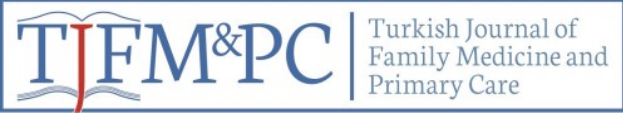

Original Research / Özgün Araştırma

\title{
The Effect of Atherosclerotic Cardiovascular Disease Risk Score Knowledge on Risk Reduction in Patients Admitted to the Obesity Center
}

\author{
Aterosklerotik Kardiyovasküler Hastalık Risk Skoru Bilgilendirmesinin Obezite \\ Merkezine Başvuran Hastalarda Risk Azalmasına Etkisi
}

Duygu İlke Ylldırım ${ }^{* 1}$, Mehmet Ali Eryılmaz ${ }^{2}$

\begin{abstract}
Objectives: Atherosclerotic cardiovascular disease (ASCVD) is the most common cause of mortality and morbidity worldwide. The aim of this study was to evaluate the effect of atherosclerotic cardiovascular disease risk score knowledge in obese patients aged 40-79 years on risk reduction in 3 months. Methods: This descriptive and cross-sectional study was approved by the clinical ethics committee. The study was conducted with 300 consecutive volunteer patients who applied to Konya Obesity Center. All patients older than 40 years of age and volunteered to participate in the study were included in the study. Patients with coronary artery disease, heart failure, major depression, treated for arrhythmias, younger than 40 years of age, and those who could not come to the follow-up 3rd-month controls were excluded. The patients admitted to the obesity center were evaluated according to the results of routine examinations. Results: Knowledge of ASCVD risk score, age, gender, occupation, marital status, diabetes, hyperlipidemia, SBP, WC, HC, TC, LDL, triglycerides, glucose, HbAlc and AST were all significantly determinants of ASCVD risk in our univariate analysis. Knowledge of ASCVD (odds ratio [OR]: 1725.917; 95\% confidence interval [CI]:208.675-14275.098; $<<0.001)$, age (OR: 0.936; 95\% CI:0.882-0.994; $p=0.030)$, gender (OR: 65.848; 95\% CI: 11.455-378.505; $\mathrm{p}<0.001$ ), occupation (OR: $0.410 ; 95 \%$ CI: 0.259-0.648; $<<0.001$ ) and total cholesterol (OR: $0.960 ; 95 \%$ Cl: $0.940-0.980 ; p<0.001)$ were defined as multivariate predictors for ASCVD risk reduction. Conclusion: In conclusion, our analysis showed that knowledge of ASCVD risk score, age, gender, occupation, and TC at admission were the most potent predictors of decrease in ASCVD risk scoring. In order to achieve risk reduction regarding CVDs, patients' awareness about knowing their CVD risk plays a crucial role.
\end{abstract}

Key words: Atherosclerotic cardiovascular disease, knowledge, risk reduction behavior, obesity

\section{ÖZET}

\begin{abstract}
Amaç: Aterosklerotik kardiyovasküler hastalık (ASKVH), dünya çapında en yaygın mortalite ve morbidite nedenidir. Bu çalışmanın amacı 40-79 yaşları arasındaki obez hastalarda aterosklerotik kardiyovasküler hastalık risk skoru bilgisinin 3 aylık dönemde risk azalmasına etkisini değerlendirmektir. Yöntem: Bu tanımlayıcı ve kesitsel çalıșma klinik etik komitesi tarafından onaylandıktan sonra çalıșma Konya Obezite Merkezine başvuran ardıșık 300 gönüllü hasta ile yapılmıştır. Çalışmaya katılmaya gönüllü olan 40 yaş üstü tüm hastalar dahil edildi. Koroner arter hastalığı, kalp yetmezliği, majör depresyon, aritmi tedavisi gören, 40 yaş altı ve üçüncü ay kontrollerine gelemeyen hastalar çalışma dıșı bırakıldı. Obezite merkezine başvuran hastalar rutin tetkik sonuçlarına göre değerlendirilmektedir. Bulgular: Tek değişkenli analizimizde ASKVH risk skoru bilgilendirmesi, yaş, cinsiyet, meslek, medeni durum, diyabet, hiperlipidemi, SBP, WC, HC, TC, LDL, trigliseridler, glikoz, HbAlc ve AST; ASKVH riskinin önemli belirleyicileriydi. ASKVH risk skoru bilgisi (olasilık oranı [OR]: 1725,917; \% 95 CI: 208,675-14275,098; $\mathrm{p}<0,001)$, yaş (OR: 0,936; \% 95 CI: 0,882-0,994; $\mathrm{p}=0,030)$, cinsiyet (OR: 65,848; \% 95 Cl: 11,455 378,505; $\mathrm{p}<0,001$ ), meslek (OR: 0,410; \% 95 Cl: 0,259-0,648; p <0,001) ve toplam kolesterol (OR: 0,960; \% 95 Cl:0,940-0,980; p <0,001) ASKVH risk azaltımı için çok değişkenli öngörücüler olarak tanımlandı. Sonuç: Sonuç olarak, analizimiz ASKVH risk skoru bilgisi, yaş, cinsiyet, meslek ve başvuru sırasında ölçülen TC bilgisinin ASCVD risk puanlamasındaki azalmanın en güçlü belirleyicileri olduğunu gösterdi. KVH'ler açısından risk azaltımı sağlamak için, hastaların KVH risklerine ilişkin farkındalıkları çok önemli bir rol oynar.
\end{abstract}

Anahtar kelimeler: Aterosklerotik kardiyovasküler hastalık, bilgi, risk azaltma davranışı, obezite

Received / Geliș tarihi: 22.09.2020, Accepted / Kabul tarihi: 18.12.2020

${ }^{1}$ Department of Family Medicine, Konya Training and Research Hospital, University of Health Sciences, Konya, TURKEY.

${ }^{2}$ Department of General Surgery, Konya Training and Research Hospital, University of Health Sciences, Konya, TURKEY.

*Address for Correspondence / Yazışma Adresi: Duygu İlke Yıldırım, Department of Family Medicine, Konya Training and Research Hospital, University of Health Sciences, Hacı Şaban Mah. Meram Yeniyol Caddesi No:97 PK: 42090 Meram, Konya, TURKEY.

E-mail: $\underline{\text { azrailla@hotmail.com }}$

Yıldırım Dİ, Eryılmaz MA. The Effect of Atherosclerotic Cardiovascular Disease Risk Score Knowledge on Risk Reduction in Patients Admitted to the Obesity Center. TJFMPC, 2021;15(1): 129-135.

DOI: $10.21763 / \mathrm{tjfmpc.798484}$ 


\section{INTRODUCTION}

Atherosclerotic cardiovascular disease (ASCVD) is the most common cause of mortality and morbidity worldwide. ${ }^{1}$ Around 17.7 million people die from CVD each year, while 8.8 million die due to cancers, 3.9 million die due to respiratory diseases, and 1.6 million die from diabetes. Since there is a high frequency of mortality in CVDs, primary prevention appears to have an influential role which should be further elucidated. Similarly, approximately $86 \%$ of deaths are principally due to CVDs, diabetes, cancer, and chronic respiratory diseases in Turkey. Besides, $80 \%$ of premature deaths caused by CVD can be prevented with the aid of appropriate risk reduction. ${ }^{2}$

CVD risk score calculation on an individual basis and informing patients about their potential prognosis may significantly reduce the prevalence of CVD by orienting the modifiable behavioral risk factors. A sedentary lifestyle, unhealthy diet, smoking, and alcohol use are among the most common divertible risk factors. The incidence of chronic diseases such as hypertension, diabetes, hyperlipidemia, and obesity, unfortunately, an increase in population due to insufficient adaptation to a healthy lifestyle in the nature of a vicious cycle. Genetic factors, socio-demographic characteristics, cultural changes, increase in the elderly population are the static determinants of CVDs. ${ }^{3-6}$ It is important to calculate a cardiovascular risk score for all people over 40 years of age and to take appropriate measures to prevent the development of conditions such as myocardial infarction (MI) and peripheral arterial disease (PAH), if possible, with appropriate interventions for modifiable risk factors.

The aim of this study was to evaluate the effect of ASCVD risk score knowledge in obese patients aged 40-79 years on risk reduction in 3 months.

\section{MATERIALS AND METHODS}

\section{Study setting}

This descriptive and cross-sectional study was approved by the clinical ethics committee. The study was conducted with 300 consecutive volunteer patients who applied to Konya Obesity Center to lose weight between 21.01.201910.11.2019 and accepted to participate in the study. All patients who were older than 40 years of age and volunteered to participate in the study were included in the study. Patients with coronary artery disease, cerebrovascular accident, peripheral arterial disease, heart failure, major depression, treated for arrhythmias, younger than 40 years of age, and those who could not come to the 3-month follow-up control visits were excluded. The patients admitted to the obesity center were evaluated according to the results of routine examinations. The baseline and 3-month ASCVD risk scores were calculated individually according to the test biochemical test results at the beginning and final visit respectively. 150 patients were informed about their calculated ASCVD risk score at the beginning, and the other 150 patients were not. Patients were allocated randomly in a 1:1 fashion to be informed about ASCVD or not. The patients with an increase or decrease in their ASCVD risk score were identified following the final visit. The study population was divided into two groups. Group 1 included patients with risk reduction and Group 2 included patients with an increase in risk according to the ASCVD risk score. The blood sample test results obtained after 3 months were compared with those measured at the time of admission. The independent predictors of risk reduction in ASCVD risk score at the 3-month follow-up have been evaluated by comparing the differences between the two groups.

Blood sample tests obtained from patients included hemogram (CBC), ALT, AST, HDL-C, LDL-C, Triglyceride, Total cholesterol (TC), TSH (Thyroid-stimulating hormone), glucose, insulin, creatinine, and urea. A questionnaire about sociodemographic characteristics with 20 questions was completed by the patients who applied to the center. We used the ASCVD algorithm defined in the 2013 ACC/AHA Guideline to calculate the 10year risk of heart disease/stroke of patients. The heart disease risk calculator includes age (40-79 years), gender, race (African American, Other), total cholesterol (130-320 mg/dL), HDL cholesterol (20-100 mg/dL), systolic blood pressure (SBP) (90$200 \mathrm{mmHg}$ ), diastolic blood pressure (DBP) (30$140 \mathrm{mmHg}$ ), treatment for high blood pressure, diabetes and smoking status. ${ }^{7}$ Ethics approval was obtained from the Ethics Committee of Necmettin Erbakan University of Medical Sciences (NMRR2019/1678).

\section{Data Collection Tools:}

\section{Socio-Demographic Data Collection Form}

Participants filled out a form to determine sociodemographic characteristics. In order to obtain personal information, the questionnaire included questions about age, height, body weight, gender, place of residence, family type, social security, and income levels. 


\section{Statistical Analysis}

All data were recorded into the IBM SPSS 22.0 statistical software package. In the evaluation of the data obtained from the study; descriptive statistical methods; frequency $(\mathrm{n})$, percentage $(\%)$, mean \pm standard deviation, min (minimum) - max (maximum) were used.

For statistical significance; Chi-square (X2) test was used to compare qualitative data, t-test and logistic regression analysis were used to compare the means of continuous variables. The normality of the data was checked by the KolmogorovSmirnov normality test. All analyzes were performed at $95 \%$ confidence interval. A p-value of $<0.05$ was considered the threshold for statistical significance.

\section{RESULTS}

The comparison of patients according to sociodemographic characteristics and some other parameters are shown in Table 1. A total of 300 patients were interviewed, 190 were female $(63.3 \%)$. The mean age of patients was $54.16 \pm$ 9.28 years (range $40-79$ years).

The frequency of female gender and patients older than 65 years are higher in group 1 compared group 2. $\quad(\mathrm{p}<0.001$ and $\mathrm{p}<0.001$ respectively $)$ Educational level does not differ between the two groups. The frequency of diabetes mellitus, hyperlipidemia and morbid obesity are higher in group 1 compared to group 2 . $(p=0.024, p<0.001$ and $\mathrm{p}<0.001$ respectively) $\mathrm{HbA} 1 \mathrm{c}$ does not differ between two groups.

\begin{tabular}{|c|c|c|c|c|c|c|c|}
\hline \multirow[t]{2}{*}{ Characteristics } & \multirow[t]{2}{*}{ Cathegory } & \multicolumn{2}{|c|}{$\begin{array}{c}\text { ASCVD Risk } \downarrow \\
\text { Group } 1(n=176)\end{array}$} & \multicolumn{2}{|c|}{$\begin{array}{r}\text { ASCVD Risk } \uparrow \\
\text { Group } 2(n=124)\end{array}$} & \multirow[b]{2}{*}{$x^{2}$} & \multirow[b]{2}{*}{$p$} \\
\hline & & $n$ & $\%$ & $n$ & $\%$ & & \\
\hline Gender & $\begin{array}{l}\text { Female } \\
\text { Male }\end{array}$ & $\begin{array}{c}134 \\
42\end{array}$ & $\begin{array}{l}76.1 \\
23.9 \\
\end{array}$ & $\begin{array}{l}56 \\
68 \\
\end{array}$ & $\begin{array}{l}45.2 \\
54.8\end{array}$ & 30.056 & $<0.001$ \\
\hline Age (years) & $\begin{array}{l}40-65 \\
66-79 \\
\end{array}$ & $\begin{array}{c}132 \\
44\end{array}$ & $\begin{array}{l}75.0 \\
25.0\end{array}$ & $\begin{array}{c}116 \\
8\end{array}$ & $\begin{array}{c}93.5 \\
6.5\end{array}$ & 17.467 & $<0.001$ \\
\hline $\begin{array}{l}\text { Educational } \\
\text { level }\end{array}$ & $\begin{array}{l}\text { Illiterate } \\
\text { Literate } \\
\text { Elementary sch. } \\
\text { High school } \\
\text { Unıversity and } \uparrow\end{array}$ & $\begin{array}{c}37 \\
28 \\
68 \\
9 \\
34\end{array}$ & $\begin{array}{c}21.0 \\
16.0 \\
38.6 \\
5.1 \\
19.3 \\
\end{array}$ & $\begin{array}{l}36 \\
16 \\
42 \\
14 \\
16\end{array}$ & $\begin{array}{l}29.0 \\
12.9 \\
33.9 \\
11.3 \\
12.9 \\
\end{array}$ & 8.068 & 0.089 \\
\hline $\begin{array}{l}\text { Marital } \\
\text { status }\end{array}$ & $\begin{array}{l}\text { Married } \\
\text { Single } \\
\text { Widow+Divorced }\end{array}$ & $\begin{array}{c}136 \\
14 \\
26\end{array}$ & $\begin{array}{c}77.2 \\
8.0 \\
14.8\end{array}$ & $\begin{array}{c}118 \\
6 \\
-\end{array}$ & $\begin{array}{c}95.2 \\
4.8 \\
-\end{array}$ & 22.127 & $<0.001$ \\
\hline Occupation & $\begin{array}{l}\text { Housewife } \\
\text { Employee } \\
\text { Retired } \\
\text { Public personnel } \\
\text { Other }\end{array}$ & $\begin{array}{c}114 \\
14 \\
22 \\
20 \\
6 \\
\end{array}$ & $\begin{array}{c}64.7 \\
8.0 \\
12.5 \\
11.4 \\
3.4 \\
\end{array}$ & $\begin{array}{c}50 \\
30 \\
24 \\
12 \\
8 \\
\end{array}$ & $\begin{array}{c}40.3 \\
24.2 \\
19.3 \\
9.7 \\
6.5 \\
\end{array}$ & 24.901 & $<0.001$ \\
\hline Income status & $\begin{array}{l}\text { High } \\
\text { Middle } \\
\text { Low }\end{array}$ & $\begin{array}{c}20 \\
34 \\
122\end{array}$ & $\begin{array}{l}11.4 \\
19.3 \\
69.3\end{array}$ & $\begin{array}{c}6 \\
40 \\
78\end{array}$ & $\begin{array}{c}4.8 \\
32.3 \\
62.9\end{array}$ & 20.496 & $<0.001$ \\
\hline $\begin{array}{l}\text { Smoking } \\
\text { status }\end{array}$ & $\begin{array}{l}\text { Smoker } \\
\text { Non-smoker } \\
\text { Ex-smoker } \\
\end{array}$ & $\begin{array}{c}14 \\
130 \\
32 \\
\end{array}$ & $\begin{array}{c}8.0 \\
73.9 \\
18.1 \\
\end{array}$ & $\begin{array}{l}15 \\
91 \\
18 \\
\end{array}$ & $\begin{array}{l}12.1 \\
73.4 \\
14.5 \\
\end{array}$ & 1.880 & 0.391 \\
\hline Diabetes & $\begin{array}{l}\text { Yes } \\
\text { No }\end{array}$ & $\begin{array}{c}30 \\
146\end{array}$ & $\begin{array}{l}17.0 \\
83.0\end{array}$ & $\begin{array}{c}10 \\
114\end{array}$ & $\begin{array}{c}8.1 \\
91.9\end{array}$ & 5.078 & 0.024 \\
\hline Hypertension & $\begin{array}{l}\text { Yes } \\
\text { No }\end{array}$ & $\begin{array}{c}22 \\
154 \\
\end{array}$ & $\begin{array}{l}12.5 \\
87.5\end{array}$ & $\begin{array}{c}22 \\
102 \\
\end{array}$ & $\begin{array}{l}17.7 \\
82.3\end{array}$ & 1.597 & 0.206 \\
\hline Hyperlipidemia & $\begin{array}{l}\text { Yes } \\
\text { No }\end{array}$ & $\begin{array}{c}48 \\
128 \\
\end{array}$ & $\begin{array}{l}27.3 \\
72.7\end{array}$ & $\begin{array}{c}4 \\
120 \\
\end{array}$ & $\begin{array}{c}3.2 \\
96.8\end{array}$ & 29.358 & $<0.001$ \\
\hline BMI-3 ${ }^{\text {rd }}$ & $\begin{array}{l}\text { Normal } \\
\text { Overweight } \\
\text { Class I Obesity } \\
\text { Class II Obesity } \\
\text { Morbid obese }\end{array}$ & $\begin{array}{l}12 \\
38 \\
76 \\
30 \\
20 \\
\end{array}$ & $\begin{array}{c}6.8 \\
21.6 \\
43.2 \\
17.0 \\
11.4 \\
\end{array}$ & $\begin{array}{c}2 \\
6 \\
68 \\
38 \\
10 \\
\end{array}$ & $\begin{array}{c}1.6 \\
4.9 \\
54.9 \\
30.6 \\
8.0 \\
\end{array}$ & 26.930 & $<0.001$ \\
\hline HbA1c-3 ${ }^{\text {rd }}$ & $\begin{array}{l}<\% 6,5 \downarrow \\
>6,5 \text { and } \uparrow\end{array}$ & $\begin{array}{c}164 \\
12\end{array}$ & $\begin{array}{c}93.2 \\
6.8\end{array}$ & $\begin{array}{c}118 \\
6\end{array}$ & $\begin{array}{c}95.2 \\
4.8\end{array}$ & 0.505 & 0.477 \\
\hline $\begin{array}{l}\text { Knowledge of } \\
\text { ASCVD risk }\end{array}$ & $\begin{array}{l}\text { Yes } \\
\text { No }\end{array}$ & $\begin{array}{c}148 \\
28\end{array}$ & $\begin{array}{l}84.1 \\
15.9\end{array}$ & $\begin{array}{c}2 \\
122\end{array}$ & $\begin{array}{c}1.6 \\
98.4\end{array}$ & 197.947 & $<0.001$ \\
\hline
\end{tabular}

ASCVD: Atherosclerotic cardiovascular disease; BMI: Body mass index; HbA1c: Hemoglobin A1c 
Half of the patients were told about ASCVD risk scoring and the other half were never mentioned. There were statistically significant differences between increased and decreased ASCVD risk scoring in terms of gender, age, marital status, occupation, income status, diabetes, hyperlipidemia, BMI, and knowledge of ASCVD risk.
Comparison of demographic, first, and final visit laboratory parameters of the two groups is presented in Table 2. At the 3-month visit; SBP, DBP, Body mass index, hip circumference, TC, HDL, LDL, glucose, insulin and TSH were significantly lower in Group 1 compared to Group 2 , while there was no statistical difference between the two groups in terms of the first month levels of DBP, BMI, HC, HDL, insulin, TSH, blood urea, creatinine and ALT (Table 2).

Table 2. Comparison of demographic, $1^{\text {st }}$ and 3 rd-month visit laboratory parameters of patients according to ASCVD risk

\begin{tabular}{|c|c|c|c|}
\hline & $\begin{array}{l}\text { ASCVD Risk } \downarrow \\
\text { Group } 1\end{array}$ & $\begin{array}{l}\text { ASCVD Risk } \uparrow \\
\text { Group } 2 \\
\end{array}$ & $p$ \\
\hline Age (years) & $56.2(48.5-65.5)$ & $51.2(45.0-55.0)$ & $<0.001$ \\
\hline SBP-1 $^{\text {st }}$ & $132.8(125.0-140.0)$ & $129.6(130.0-135.0)$ & $\mathbf{0 . 0 3 7}$ \\
\hline SBP-3 ${ }^{\text {rd }}$ & $122.2(120.0-130.0)$ & $135.1(130.0-140.0)$ & $<0.001$ \\
\hline DBP-1 ${ }^{\text {st }}$ & $83.3(75.0-90.0)$ & $83.1(80.0-85.0)$ & 0.744 \\
\hline DBP-3 $3^{\text {rd }}$ & $77.6(72.5-80.0)$ & $87.9(80.0-90.0)$ & $<0.001$ \\
\hline BMI-1 $^{\text {st }}$ & $35.1(31.2-38.4)$ & $34.5(31.9-36.4)$ & 0.766 \\
\hline BMI-3 ${ }^{\text {rd }}$ & $32.9(29.3-35.0)$ & $34.6(31.6-36.5)$ & 0.001 \\
\hline $\mathrm{WC} \mathbf{1}^{\text {st }}$ & $112.5(106.0-115.0)$ & $109.1(105.0-114.0)$ & 0.004 \\
\hline $\mathrm{WC}-3^{\text {rd }}$ & $107.5(101.0-111.0)$ & $107.9(102.0-114.0)$ & 0.297 \\
\hline HC-1 ${ }^{\text {st }}$ & $127.1(124.0-129.0)$ & $125.0(123.0-128.0)$ & 0.196 \\
\hline $\mathrm{HC}-3^{\text {rd }}$ & $122.1(118.0-125.0)$ & $124.0(118.0-130.0)$ & 0.015 \\
\hline TC-1 ${ }^{\text {st }}$ & $257.4(228.5-287.0)$ & $225.0(207.0-253.0)$ & $<0.001$ \\
\hline TC-3 ${ }^{\text {rd }}$ & $222.7(197.5-253.0)$ & $240.7(223.0-263.0)$ & $<0.001$ \\
\hline HDL-1 $^{\text {st }}$ & $53.1(44.0-60.5)$ & $52.0(45.0-59.0)$ & 0.473 \\
\hline HDL-3 ${ }^{\text {rd }}$ & $54.5(49.0-61.0)$ & $50.5(44.0-53.0)$ & $<0.001$ \\
\hline LDL-1 $^{\text {st }}$ & $172.7(144.0-196.0)$ & $150.5(131.0-176.0)$ & $<0.001$ \\
\hline LDL-3 $^{\text {rd }}$ & $145.2(124.0-168.0)$ & $160.2(144.0-188.0)$ & $<0.001$ \\
\hline Triglycerides- $1^{\text {st }}$ & $169.8(108.5-227.0)$ & $129.8(91.0-157.0)$ & $<0.001$ \\
\hline Triglycerides- $3^{\text {rd }}$ & $146.6(87.0-183.0)$ & $144.6(105.0-164.0)$ & 0.394 \\
\hline Glucose-1 $^{\text {st }}$ & $101.8(89.5-112.0)$ & $96.4(86.0-98.0)$ & $<0.001$ \\
\hline Glucose- $3^{\text {rd }}$ & $96.2(89.0-100.0)$ & $108.0(98.0-113.0)$ & $<0.001$ \\
\hline Insulin-1 $^{\text {st }}$ & $12.3(6.2-16.3)$ & $10.5(6.1-12.0)$ & 0.051 \\
\hline Insulin-3 ${ }^{\text {rd }}$ & $9.5(5.8-12.0)$ & $12.2(7.8-12.7)$ & $<0.001$ \\
\hline HbA1c-1 ${ }^{\text {st }}$ & $5.9(5.6-6.2)$ & $5.7(5.5-5.8)$ & $<0.001$ \\
\hline HbA1c-3 ${ }^{\text {rd }}$ & $5.7(5.4-5.9)$ & $5.8(5.5-5.9)$ & 0.611 \\
\hline TSH-1 $^{\text {st }}$ & $2.6(1.5-3.0)$ & $2.6(1.7-3.2)$ & 0.167 \\
\hline TSH-3 ${ }^{\text {rd }}$ & $2.0(1.3-2.5)$ & $2.7(1.9-3.2)$ & $<0.001$ \\
\hline Blood urea-1 ${ }^{\text {st }}$ & $27.5(22.0-32.5)$ & $28.3(24.0-33.0)$ & 0.324 \\
\hline Blood urea-3 ${ }^{r}$ & $25.0(20.0-31.0)$ & $26.6(21.0-32.0)$ & 0.316 \\
\hline Creatinine-1 $^{\text {st }}$ & $0.78(0.71-0.83)$ & $0.79(0.72-0.81)$ & 0.719 \\
\hline Creatinine- $3^{\text {rd }}$ & $0.79(0.70-0.86)$ & $0.77(0.68-0.82)$ & 0.063 \\
\hline AST-1 ${ }^{\text {st }}$ & $26(18-27)$ & $21(16-23)$ & $<0.001$ \\
\hline AST-3 ${ }^{\text {rd }}$ & $23.5(17.0-25.0)$ & $26.4(16.0-31.0)$ & 0.418 \\
\hline ALT-1 ${ }^{\text {st }}$ & $26(13-26)$ & $23(15-27)$ & 0.373 \\
\hline ALT-3 ${ }^{\text {rd }}$ & $24.0(14.0-26.0)$ & $27.9(16.0-32.0)$ & 0.206 \\
\hline
\end{tabular}

Values are presented as mean \pm standard deviation. Statistical analysis was done by Mann-Whitney U-test for first and third-month values. ASCVD: Atherosclerotic cardiovascular disease; SBP: systolic blood pressure; DBP: diastolic blood pressure; BMI: body mass index; WC: waist circumference; HC: hip circumference; TC: Total cholesterol; HDL: High-density lipoprotein; LDL: Low-density lipoprotein; TG: Triglycerides; HbA1c: Hemoglobin A1c; TSH: Thyroid-stimulating hormone; AST: Aspartate aminotransferase; ALT: Alanine aminotransferase.

The univariate and multivariate logistic regression predictors of ASCVD risk are indicated in Table 3 and Table 4. 


\section{Table 3. Univariate logistic regression analysis of demographic and 1st-month laboratory parameters determinants of decrease in ASCVD}

\begin{tabular}{lcc} 
Univariate analysis & $\boldsymbol{p}$ & OR (95\% CI) \\
\hline Knowledge of ASCVD & $<0.001$ & $322.429(75.298-1380.653)$ \\
\hline Age & $<0.001$ & $0.938(0.913-0.965)$ \\
\hline Gender, female & $<0.001$ & $3.874(2.361-6.357)$ \\
\hline Occupation & 0.036 & $1.172(1.011-1.359)$ \\
\hline Marital status & $<0.001$ & $0.247(0.120-0.511)$ \\
\hline Diabetes & 0.027 & $2.342(1.099-4.991)$ \\
\hline Hyperlipidemia & $<0.001$ & $11.250(3.937-32.147)$ \\
\hline SBP & 0.037 & $1.044(1.030-1.056)$ \\
\hline WC & 0.002 & $1.050(1.034-1.066)$ \\
\hline HC & 0.024 & $1.065(1.043-1.086)$ \\
\hline TC & $<0.001$ & $1.210(1.102-1.320)$ \\
\hline LDL & $<0.001$ & $1.082(1.066-1.098)$ \\
\hline Triglycerides & $<0.001$ & $1.108(1.090-1.126)$ \\
\hline Glucose & 0.029 & $1.044(1.033-1.057)$ \\
\hline HbA1c & $<0.001$ & $2.349(1.855-2.890)$ \\
\hline AST & 0.044 & $1.048(1.005-1.081)$ \\
\hline ASCVD: Atherosclerotic cardiovascular disease; SBP: systolic blood pressure; DBP: diastolic blood pressure; WC: waist \\
circumference; HC: hip circumference; TC: Total cholesterol; LDL: Low-density lipoprotein; HbA1c: Hemoglobin A1c; AST: \\
Aspartate aminotransferase; OR: Odds ratio; Cl: Confidence interval.
\end{tabular}

Knowledge of ASCVD, age, gender, occupation, marital status, diabetes, hyperlipidemia, SBP, WC, $\mathrm{HC}, \mathrm{TC}, \mathrm{LDL}$, triglycerides, glucose, HbA1c and AST were all significantly determinants of ASCVD risk in the univariate analyzes (Table 3). Knowledge of ASCVD (odds ratio [OR]: 1725.917; 95\% Cl:208.675-14275.098; $\mathrm{p}<0.001$ ), age (OR:
0.936; 95\% Cl:0.882-0.994; $\mathrm{p}=0.030)$, gender (OR: 65.848; 95\% Cl: 11.455-378.505; $\mathrm{p}<0.001)$, occupation (OR: 0.410; 95\% Cl: 0.259-0.648; $\mathrm{p}<0.001)$ and TC (OR: 0.960; 95\% Cl: 0.940$0.980 ; \mathrm{p}<0.001)$ were defined as multivariate predictors for ASCVD risk reduction (Table 4).

\section{Table 4. A multivariate analysis demonstrating independent predictors of decrease in ASCVD}

\begin{tabular}{lcc}
\hline Multivariate analysis & $\boldsymbol{p}$ & OR (95\%Cl) \\
\hline Knowledge of ASCVD & $<0.001$ & $1725.937(208.675-14275.098)$ \\
\hline Age & 0.030 & $0.936(0.882-0.994)$ \\
\hline Gender, female & $<0.001$ & $65.848(11.455-378.505)$ \\
\hline Occupation & $<0.001$ & $1.410(1.243-1.648)$ \\
\hline TC & $<0.001$ & $1.155(1.090-1.210)$ \\
\hline
\end{tabular}

ASCVD: Atherosclerotic cardiovascular disease; TC: Total cholesterol; OR: Odds ratio; Cl:Confidence interval.

\section{DISCUSSION}

Our study is the first investigation in the literature evaluating the effect of informing patients about ASCVD risk score on cardiovascular risk reduction. As a result of the current study, informing patients about their ASCVD risk score is an independent predictor of CVD risk reduction based on the decrease in the ASCVD risk score. Age, gender, occupation, and TC levels at admission were the other independent predictors of ASCVD risk reduction at the 3-month visit.

Our study revealed that the predicted 10-year ASCVD risk of our patients on their first visit was $8.4 \pm 8.1 \%$, after 3 months $6.6 \pm 7.1 \%$. According to the 2013 ACC/AHA cholesterol guideline, patients (40-75 years) with no diabetes but with LDL cholesterol 70 to $189 \mathrm{mg} / \mathrm{dL}$, predicted 10 year ASCVD risk was $\geq 7.5 \%$ which also defined the patients with very high risk. ${ }^{7}$ Thus, it is easy to infer that in our obesity center we are dealing with a group of obese patients who are at very high risk for cardiovascular disease (mean ASCVD risk 8.4 $\pm 8.1 \%$ ). The study population corresponds to a very suitable sample with its very high baseline risk to test the effect of informing patients about ASCVD risk in three months period. Although three months period can be interpreted as insufficient for a significant change in risk reduction at first view, our results demonstrated the importance of patient enlightenment in primary prevention for CVDs in this short period.

Age always appears as an unalterable and inevitable risk factor for all cardiovascular diseases. ${ }^{8}$ However, in our study, age was proved to be an independent predictor for ASCVD risk reduction, elder patients did not achieve significant risk reduction according to their calculated ASCVD. The patient's psychological status, compliance with lifestyle changes, and orthopedic excuses for exercise may have a role in this result. ${ }^{9}$ In the literature, age has been recurrently 
demonstrated as a determinant of doctor recommendations and medication compliance. ${ }^{10}$ Similarly, in our study we could not achieve a significant reduction in ASCVD in elder patients.

In a study enrolled in adult patients with myocardial infarction, female patients were less likely to meet physical activity recommendations. ${ }^{11}$ Moreover, female patients were more likely to withdraw from the cardiac rehabilitation program than men because of the higher frequency of medical problems. ${ }^{12}$ On the other hand, in our study, the female gender was found to be an independent predictor of risk reduction based on ASCVD risk calculation. The higher frequency of female gender in the study population may be the underlying reason for this result.

TC level is the other important component of ASCVD risk calculation? ${ }^{7}$ Dyslipidemia, diabetes, and hypertension are well-known risk factors for ASCVD as assigned in previous studies and guidelines. $^{7,13,14}$ Despite the shortness of the three months, the patient accomplished a notable decrease in TC level. In our investigation, a higher TC level at admission was also found to be an independent predictor of risk reduction in ASCVD risk calculation. Lifestyle modification was shown to have a greater effect in very high-risk patients in primary prevention ${ }^{15}$. Therefore, our results were compatible with the current data in the literature.

There were controversial studies about disease knowledge and patient compliance in terms of chronic disease management. ${ }^{16-19}$ After we investigated the disease knowledge in a large population with obese patients, we found out that patients tended to decrease their CVD risk with higher compliance if they have an awareness about their CVD risk. Even though we performed a study for primary prevention in a short period, accurate enlightenment of patients about their current status established its power in obese very high-risk patients. As a result, physicians need to contact their patients in a trustworthy way, clarify the definition and potential risks of the mentioned disease to maintain general well-being both in primary and secondary prevention.

\section{STUDY LIMITATIONS}

The current study has several limitations. Firstly; this was a single-center and observational study; therefore, our study has a limited value for generalizability. Secondly, our study's objectivity may be limited since physicians informed patients about their potential risks in terms of CVDs on an individual basis.

\section{CONCLUSION}

In conclusion, our analysis depicted knowledge of ASCVD, age, gender, occupation, and TC at admission were the independent predictors of the decrease in ASCVD risk scoring. Informing patients plays a crucial role to achieve risk reduction in regards to CVDs.

\section{FUNDING}

There was no funding for the study.

\section{DECLARATIONS OF INTEREST}

None.

\section{REFERENCES}

1. Benjamin EJ, Muntner P, Alonso A, Bittencourt MS, Callaway CW, Carson AP, et al. Heart Disease and Stroke Statistics-2019 Update: A Report From the American Heart Association. Circulation. 2019;139(10):e56-e528.

2. Şencan İ, Keskinkılıç B, Ekinci B, Öztemel A, Sarıoğlu G, Çobanoğlu N, et al. Türkiye Kalp ve Damar Hastalıkları Önleme ve Kontrol Programı [Available from: https://www.tkd.org.tr/TKDData/Uploads/files/Tur kiye-kalp-ve-damar-hastaliklari-onleme-ve-kontrolprogrami.pdf.

3. Molvin J, Jujic A, Nilsson PM, Leosdottir M, Lindblad U, Daka B, et al. A diabetes-associated genetic variant is associated with diastolic dysfunction and cardiovascular disease. ESC Heart Failure. 2019;7(1):348-356.

4. Gidding SS. Familial Hypercholesterolemia: now part of cardiovascular disease genetic epidemiology research. Journal of the American College of Cardiology; 2016;67(22):2590-2592.

5. Zhang Y, Chen Y, Ma L. Depression and cardiovascular disease in elderly: Current understanding. Journal of Clinical Neuroscience. 2018;47:1-5.

6. Lear SA, Hu W, Rangarajan S, Gasevic D, Leong D, Iqbal $\mathrm{R}$, et al. The effect of physical activity on mortality and cardiovascular disease in 130000 people from 17 high-income, middleincome, and low-income countries: the PURE study. The Lancet. 2017;390(10113):2643-54.

7. Goff DC, Lloyd-Jones DM, Bennett G, Coady S, D’Agostino RB, Gibbons R, et al. 2013 ACC/AHA guideline on the assessment of cardiovascular risk: a report of the American College of Cardiology/American Heart Association Task Force on Practice Guidelines. Journal of the American College of Cardiology. 2014;63(25 Part B):2935-59

8. Karmali KN, Goff DC, Ning H, Lloyd-Jones DM. A systematic examination of the 2013 
ACC/AHA pooled cohort risk assessment tool for atherosclerotic cardiovascular disease. Journal of the American College of Cardiology. 2014;64(10):959-68.

9. Morris CK, Ueshima K, Kawaguchi T, Hideg A, Froelicher VF. The prognostic value of exercise capacity: a review of the literature. American heart journal. 1991;122(5):1423-31.

10. Slymen DJ, Drew JA, Elder JP, Williams SJ. Determinants of non-compliance and attrition in the elderly. International journal of epidemiology. 1996;25(2):411-9.

11. Minges KE, Strait KM, Owen N, Dunstan DW, Camhi SM, Lichtman J, et al. Gender differences in physical activity following acute myocardial infarction in adults: a prospective, observational study. European journal of preventive cardiology. 2017;24(2):192-203.

12. Marzolini S, Brooks D, Oh PI. Sex differences in completion of a 12-month cardiac rehabilitation programme: an analysis of 5922 women and men. European Journal of Cardiovascular Prevention \& Rehabilitation. 2008;15(6):698-703.

13. Kim K-i, Kim M-A, Kim MK, Kim S-H, Kim HS, Moon MK, et al. 2015 Korean guidelines for the management of dyslipidemia: executive summary (English translation). Korean circulation journal. 2016;46(3):275.

14. Kim H, Kim S, Han S, Rane PP, Fox KM, Qian $\mathrm{Y}$, et al. Prevalence and incidence of atherosclerotic cardiovascular disease and its risk factors in Korea: a nationwide population-based study. BMC public health. 2019;19(1):1112.

15. National Clinical Guideline Centre (UK). Lipid modification: cardiovascular risk assessment and the modification of blood lipids for the primary and secondary prevention of cardiovascular disease. 2014.

16. Nadeem MK, Mari A, Iftikhar S, Khatri A, Sarwar T, Patel MJ. Hypertension-related Knowledge and Its Relationship with Blood Pressure Control in Hypertensive Patients Visiting a Semi-private Tertiary-care Charity Hospital in Karachi, Pakistan. Cureus. 2019;11(10).

17. Shamsi A, Nayeri ND, Esmaeili M. Living with hypertension: A qualitative research. International journal of community based nursing and midwifery. 2017;5(3):219.

18.Pelin, M. (2017). Kronik hastalık yönetiminde hasta rolü, yaşam kalitesi ve tedaviye uyumun değerlendirilmesi. Sakarya Ünivetrsitesi, Master's thesis, 2017.

19. Anadol, Z., Dişçigil, G. Hipertansif Hastalarda tedavi uyumunu etkileyen faktörler. Türkiye Klinikleri Cardiovascular Sciences, 2009;21(2): 184-190. 